\title{
Optimization of reinforced concrete beams using Solver tool
}

\section{Otimização de vigas de concreto armado utilizando a ferramenta Solver}
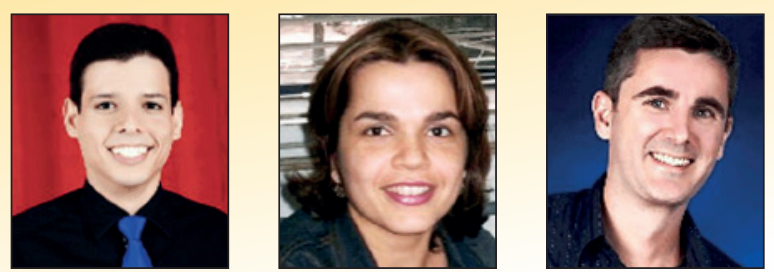

R. S. CORREIA rubenssilvacorreia@gmail.com https://orcid.org/0000-0002-5378-385X

G. F. F. BONO giuliana.franca@gmail.com https://orcid.org/0000-0002-3668-135X

G. BONO https://orcid.org/0000-0003-4666-8703

\section{Abstract}

Due to the development in structural analysis studies, optimization techniques have become part in the design of reinforced concrete structures. Making it possible to design structures with optimized cross-sections. Thus, the present study aims to implement optimization techniques, using the Solver tool, to design procedure of reinforced concrete beams following the precepts of Brazilian Standard ABNT NBR 6118:2014. Focusing to minimize the cost of reinforced concrete beams, where the design variables are the height and width of the beam cross-section and the constraints are imposed by the relevant technical standards and design variables limitations.

Keywords: structural optimization, beams, reinforced concrete.

\section{Resumo}

Com os avanços nos estudos de análise estrutural, técnicas de otimização passaram a fazer parte do dimensionamento das estruturas de concreto armado. Por meio de tais técnicas, é possível conceber estruturas com seções otimizadas. Assim, o presente estudo tem por objetivo implementar técnicas de otimização, utilizando a ferramenta Solver, ao processo de dimensionamento de vigas de concreto armado, seguindo os preceitos da Norma Brasileira ABNT NBR 6118:2014. Será minimizado o custo das vigas de concreto armado, onde as variáveis de projeto são a altura e a base da seção transversal da viga e as restrições são imposições das normas técnicas pertinentes e limitações das variáveis de projeto.

Palavras-chave: otimização estrutural, vigas, concreto armado. 


\section{Introduction}

The construction industry has great importance in the sustainable development context, not only by its contribution to the economy, but also for its great social and environmental impacts. A sustainable build approach consists in minimizing the consumption of natural resources and maximize their reuse. In this sense, a competitive advantage for companies in this sector is the reduction of material used in construction. That is why companies have been constantly investing new techniques of waste minimization and, consequently, seeking to reduce the total cost of the project [1]. In recent years, due to the high computational development, complex structures can be analyzed through structural calculation software, making it the most economical structures design [2].

In general, the conventional design of reinforced concrete structures is a process of trial and error, where the dimensions of the structural elements are estimated and adopted if the criteria of safety and service are met. Although, this procedure does not always lead to the best economic and structural solution.

Since there are many possible solutions, the most appropriate choice can be determined using mathematical optimization techniques. Nowadays, there are various tools of structural analysis and design, however optimization tools are not commonly used in the design of reinforced concrete structures.

The mathematical optimization can be used as a tool to aid the designer in decision-making, from the definition of initial dimensions of the structural elements to their final design, eliminating the trial and error process, consequently, reducing the time of projects elaboration. There are various software capable to solve optimization problems, such as MATLAB, Octave, Scilab, Dakota, Solver, among others. Several optimization studies [3-6] of reinforced concrete beams used MATLAB, while others [7-12] used Solver. The advantages of Solver, when compared to others, are the easy use and no specific programing knowledge is required. Besides, Solver is used in $\mathrm{Mi}$ crosoft Excel worksheets, a tool widely used in engineering.

The optimization studies [7-12] of reinforced concrete beams using Solver, usually, seek to determine parameters of the beam crosssection, aiming to minimize costs associated to restrictions of relevant technical standards.

Maia [7], in his optimization study, obtained the height of the beam and the reduction factor of negative bending moment that minimize the costs. Through the study of several examples, the author has proved the efficiency of optimization through Solver.

Kripka and Pagnussat [8] determined the optimal height of the beam to minimize the costs, taking into account shear reinforcements, it was verified that the optimum height was close to the usual estimated by the design. Bhalchandra and Adsul [9], instead of height, optimized the width, steel areas and nominal cover of the beam to minimize the amount of material, using methods of Genetic Algorithms (AG) from MATLAB and the Generalized Reduced Gradient (GRG) from Solver, reporting that the AG presented the best results. Rahmanian, Lucet and Tesfamariam [10], Junior and Oliveira [11] added some aspects when formulating the optimization problem that were considered in previous studies. Both works considered commercial diameters in order to determine the steel areas. In addition, Rahmanian, Lucet and Tesfamariam [10] added the restriction limitation of cracks to beams optimization.
Rahmanian, Lucet and Tesfamariam [10] determined the height and steel area that minimize the beam cost through Solver AG and GRG, reporting a better efficiency to the GRG. Junior and Oliveira [11] obtained the cross-section dimensions, strength of the concrete and reinforcements diameter that minimize the beam cost. Concluding that the great height is close to the usual height estimate by the design and that the optimized solution presents a significant material saving when compared to other solutions.

Fraga and Kripka [12], unlike previous works, obtained the beam's optimal height to minimize financial and environmental costs, associated to the environmental impact that the beam causes. The behavior of the optimal height was obtained by the variation of the problem parameters, being verified that the use of concrete with less resistance reduces the financial and environmental costs.

It is in this context, this work proposes to incorporate optimization techniques, using Solver tool, to the procedure of design and verification of the ultimate load capacity of reinforced concrete beams, following the precepts of the Brazilian Standard ABNT NBR 6118:2014 [13]. The beams of reinforced concrete were designed in order to obtain rectangular cross-sections, optimized for situations with different variations of beam spans, loads and classes of characteristic compressive strength of the concrete. Thus, it is intended to highlight the material saving obtained by optimization techniques, by comparing the optimized cross-sections with the conventional procedure.

\section{Optimal design of reinforced concrete beams}

The aim is to find optimal values of the design variables, therefore the objective function is minimized and the constraints are satisfied. The corresponding optimization problem has the form:

$$
\begin{gathered}
\text { Minimize: } f(\boldsymbol{x}) \\
\text { Subject to: } \\
h_{j}(\boldsymbol{x})=0, \quad j=1, \ldots, m \\
g_{k}(\boldsymbol{x}) \leq 0, \quad k=1, \ldots, p \\
x_{i}^{\min } \leq x_{i} \leq x_{i}^{\max }, \quad i=1, \ldots, n
\end{gathered}
$$

Where, $f(x)$ is the objective function to be optimized, $\mathrm{x}=\left\{\mathrm{x}_{1}, \mathrm{x}_{2}, \ldots, \mathrm{x}_{\mathrm{n}}\right\}^{\top}$ is a vector that contains the project variables, $\mathrm{n}$ is the number of project variables, $h_{j}(x)$ are the equality constraints, $m$ is the total number of equality constraints, $g_{k}(x)$ are inequality constraints, $p$ is the total number of inequality constraints, $x_{i}^{\text {min }}$ and $x_{i}^{\max }$ are the side constraints. The project variables are those that can change during the optimization process and can adopt any value defined in the viable solutions. The constraints describe undesirable design situations, such as limits of stress, displacements, crack opening, among others.

After transforming the reinforced concrete beams design into a mathematical optimization problem, it is possible to find the most economical solution among several possible solutions. In this work, the beams cost will be minimized, therefore the design variables are height $(\mathrm{h})$ and width (b) of the cross-section and the restrictions are imposed by the relevant technical standards and project variables limitations. 
For the objective function, the unitary costs of steel, formworks and concrete were considered. Table 1 presents the costs extracted from the price tables of the SINAPI [14] (National system of research costs and indexes of Civil construction) for the Pernambuco state and the MASTERMIX company from Caruaru (PE).

For the steel costs $\left(C_{A}\right)$, two terms were considered: the first one concerning the cost of longitudinal reinforcements and the second one for the shear reinforcements, Eq. (2). It must be highlighted that the costs of longitudinal bars are composed of the costs of tensile, compression and skin reinforcements.

$C_{A}=A_{A l} L_{A l} \rho P_{A l}+A_{A t} L_{A t} n_{A t} \rho P_{A t}$

Where, $A_{A l}$ is the cross-section area of the longitudinal reinforcement, $L_{A l}$ is the total length of the longitudinal reinforcement, $\rho$ is the steel specific mass $\left(7850 \mathrm{~kg} / \mathrm{m}^{3}\right), \mathrm{P}_{\mathrm{Al}}$ is the unitary cost of longitudinal reinforcement $(R \$ / \mathrm{kg}), A_{A t}$ is the cross-section area of the transverse reinforcement, $L_{A t}$ is the total length of the transverse reinforcement, $n_{A t}$ is the number of transverse reinforcement contained in the beam and $\mathrm{P}_{\mathrm{At}}$ is the unitary cost of the transverse reinforcement $(\mathrm{R} \$ / \mathrm{kg})$.

The cost of formworks $\left(\mathrm{C}_{\mathrm{F}}\right)$ was calculated by Eq. (3) and the concrete cost $\left(C_{C}\right)$ was calculated according to Eq. (4):

$C_{F}=(b+2 h) L_{e f} P_{F}$

$C_{C}=b h L_{e f} P_{C}$

In which $\mathrm{b}$ and $\mathrm{h}$ are the width and height of the cross-section, respectively, $L_{e f}$ is the effective span and $P_{F}$ and $P_{C}$ are the unitary costs of the formworks $\left(R \$ / \mathrm{m}^{2}\right)$ and concrete $\left(R \$ / \mathrm{m}^{3}\right)$, respectively. Thus, the objective function $(\mathrm{C})$ was given by the sum of the costs $\mathrm{C}_{\mathrm{A}}, \mathrm{C}_{\mathrm{F}}$ and $\mathrm{C}_{\mathrm{C}}$.

The restrictions imposed to the problem studied were:

- According to the 17.4.2.1 item of ABNT NBR 6118:2014 standard [13], the shear force calculation $\left(V_{\text {sd }}\right)$ must be less or equal to the shear force resisted, related to the rupture by diagonal compression $\left(\mathrm{V}_{\mathrm{Rd} 2}\right)$ :

\section{Table 1}

Unitary costs of concrete, steel and formworks

\begin{tabular}{|c|c|c|}
\hline \multicolumn{3}{|c|}{ Concrete } \\
\hline Source & Type & $\begin{array}{c}\text { Price } \\
\left(\mathrm{R} \$ / \mathrm{m}^{3}\right)\end{array}$ \\
\hline 94964 - SINAPI 12/2016 & $\mathrm{C} 20$ & 258.97 \\
\hline 94965 - SINAPI 12/2016 & $\mathrm{C} 25$ & 252.39 \\
\hline 94966 - SINAPI 12/2016 & C30 & 260.52 \\
\hline MASTERMIX/CARUARU & C35 & 298.00 \\
\hline 94968 - SINAPI 12/2016 & $\mathrm{C} 40$ & 299.64 \\
\hline \multicolumn{3}{|c|}{ CA-50 steel } \\
\hline Source & $\begin{array}{l}\text { Diameter } \\
(\mathrm{mm})\end{array}$ & $\begin{array}{c}\text { Price } \\
(\mathrm{R} \$ / \mathrm{kg})\end{array}$ \\
\hline- & 5 & 9.47 \\
\hline 92760 - SINAPI 12/2016 & 6.3 & 9.47 \\
\hline 92761 - SINAPI 12/2016 & 8 & 9.14 \\
\hline 92762 - SINAPI 12/2016 & 10 & 7.43 \\
\hline 92763 - SINAPI 12/2016 & 12.5 & 6.17 \\
\hline 92764 - SINAPI $12 / 2016$ & 16 & 4.85 \\
\hline
\end{tabular}

\begin{tabular}{cc}
\hline \multicolumn{2}{c}{ Formworks } \\
\hline Source & $\begin{array}{c}\text { Price } \\
\left(\mathrm{R} \$ / \mathrm{m}^{2}\right)\end{array}$ \\
\hline $92446-$ SINAPI $12 / 2016$ & 119.03 \\
\hline
\end{tabular}

$V_{s d} \leq V_{R d 2}$

When it is necessary to use more than one layer of bars in the cross-section of the beam, the distance from the center of gravity of the bars (a) to the center of the farthest bar must be less than $10 \%$ of the height $(\mathrm{h})$, according to the 17.2.4.1 item of the ABNT NBR 6118:2014 standard [13]:

$a \leq 0,10 h$

- In accordance to the 17.3.5.2.4 item of ABNT NBR 6118:2014 standard [13], the sum of the tensile $\left(A_{s}\right)$ and compression $\left(A_{s}{ }^{\prime}\right)$ reinforcements must not be greater than $4 \%$ of the concrete area of the section $\left(A_{c}\right)$ :

$A_{s}+A_{s}{ }^{\prime} \leq 0,04 A_{c}$

In the verification of the Limit State of Excessive Deformation, according to ABNT Standard NBR 6118:2014 [13], the total displacement $a_{t}$ must not exceed the $a_{\text {tim }}$ limit value indicated in Table 13.3 of the aforementioned standard, and this study is considered the displacement limit for visual acceptability:

$a_{t} \leq a_{t l i m}$

The Crack Opening Limit State was verified according to the 17.3.3.2 item of ABNT NBR 6118:2014 standard [13]. The magnitude of crack opening (w) must comply with the limit value $\mathrm{w}_{\text {lim }}$ stipulated by the standard $(0.3 \mathrm{~mm}$ for Environmental Aggressiveness Class II):

$w \leq w_{\text {lim }}$

The design variables, height (h) and width (b), must be an integer with the following side constraints:

$h=h_{\text {int }}$

$b=b_{\text {int }}$

$25 \mathrm{~cm} \leq h \leq 100 \mathrm{~cm}$

$12 \mathrm{~cm} \leq b \leq 20 \mathrm{~cm}$

Based on the definitions of the project variables, objective function and constraints, the authors were able to describe mathematically the problem:

$$
\begin{gathered}
\text { Minimize: } C(h, b) \\
\text { Subject to: } \\
V_{s d} \leq V_{R d 2} \\
a \leq 0,10 h \\
A_{s}+A_{s}^{\prime} \leq 0,04 A_{C} \\
a_{t} \leq a_{t l i m} \\
w \leq w_{\text {lim }} \\
h=h_{\text {int }} \\
b=b_{\text {int }} \\
25 \leq h \leq 100 \\
12 \leq b \leq 20
\end{gathered}
$$

Thus, the optimization problem is to find the width (b) and the height $(\mathrm{h})$ of the beam cross-section to minimize the cost $(\mathrm{C})$, respecting the constraints imposed.

The optimized design steps are in Figure 1. After an initial solution 
( $b$ and $h$ ), the parameters required to calculate the objective function and the constraints (Eq. (14)) were determined. Then, it is verified if the optimal solution was found. If it is positive, the process ends, otherwise the solution is modified, repeating the process until it converges to the optimal solution.

The steel areas are designed to bending moment and shear force, ensuring that the resistive force are greater or equal to the calculation force in the beam cross-section. The steps to design reinforced concrete beam will be described next. First, based on the input data, the program is capable to calculate the effective span, the active loads and the modulus of elasticity of the concrete. Then, the force calculations on the beam are determined. Based on that, the beam is designed to the bending moment and the shear force, determining the steel areas. Afterwards, the detailing of the shear and longitudinal reinforcements is carried out. Then, parameters associated to the verification of the Serviceability Limit States (SLS): Excessive Deformations and Cracks Opening. Finally, the skin reinforcement is determined (if necessary) and the anchorage is defined. These steps are set out in Figure 1.

It is worth pointing out that, for the optimized design carried out in this work, the following considerations were adopted:

- It was considered the possibility of double reinforcement in the design to the moment bending, when necessary;

- As mentioned previously, if necessary, it was considered the possibility to apply a skin reinforcement, with a $6.3 \mathrm{~mm}$ diameter in this this type of reinforcement;

- In the design of the shear reinforcement (stirrups), the authors considered commercial diameters up to $12.5 \mathrm{~mm}$ for the CA50 steel. The choice of diameter and spacing was made in a way to approximate as much as possible to the calculated steel area, respecting the impositions made by the ABNT NBR 6118:2014 standard [13]. Considering the distribution of the stirrups along the span, detailing the support regions and central span (with minimal shear reinforcement);

- In the detailing of the longitudinal reinforcement, commercial diameters up to $16 \mathrm{~mm}$ for the CA-50 steel were considered, since larger diameters are more common in large constructions. The choice of the bars layout in the cross-section follows the requirements of ABNT NBR 6118:2014 standard [13]. First, it is tried to dispose the bars in a single layer, in order to approach the maximum of the calculated steel area, when this is not possible, the disposition occurs in several layers;

- When calculating the maximum displacements, the possibility of upward midspan deflection is considered, in order to decrease the final displacements;

- To determine the anchorage of the tensile reinforcement, a straight anchorage of all the bars is attempted as first approach. When this is not possible, the authors place hooks in the bars of the first layer. If the hook solution is not possible, clamps are used along with the hooks. The anchorage of the compression and skin reinforcements, when they exist, are straight anchorage type. The anchoring of the stirrups is also taken into consideration.

\section{Optimization tool: Analytic Solver Platform}

The program used to optimize design of reinforced concrete beam was implemented in an Excel spreadsheet, in order to use the Analytic Solver Platform [15]. This tool was developed by Frontline Systems [16] to solve optimization problems written in Excel spreadsheets. This work used the version 2016-R3 of Solver. The problem information, such as the objective function, project variables and the constraints are inserted in the worksheet cells of Solver dialog box. Then, the most appropriate optimization method for problem analysis must be selected.

There are three optimization methods in Solver: LP Simplex, the nonlinear GRG and the Evolutionary. The LP Simplex method is used for linear optimization problems [17-18]. The nonlinear GRG method is used for nonlinear type problems. The Evolutionary method is applied in complex nonlinear type problems [17].

The non-linear GRG method is based on the Generalized Reduced Gradient method, which is an extension of the Reduced Gradient method to resolve problems with nonlinear inequality constraints. [18-19]. The Evolutionary method is based on the method of genetic algorithms, defined as a technique of optimization and search based on the principles of genetics and natural selection [20], being quite applied by scientists and engineers to solve practical problems [21].

To determine what is the most appropriate method for solving the optimization problem, Solver has a feature called "Analyze without Solving", where convexity tests are made to know the type of

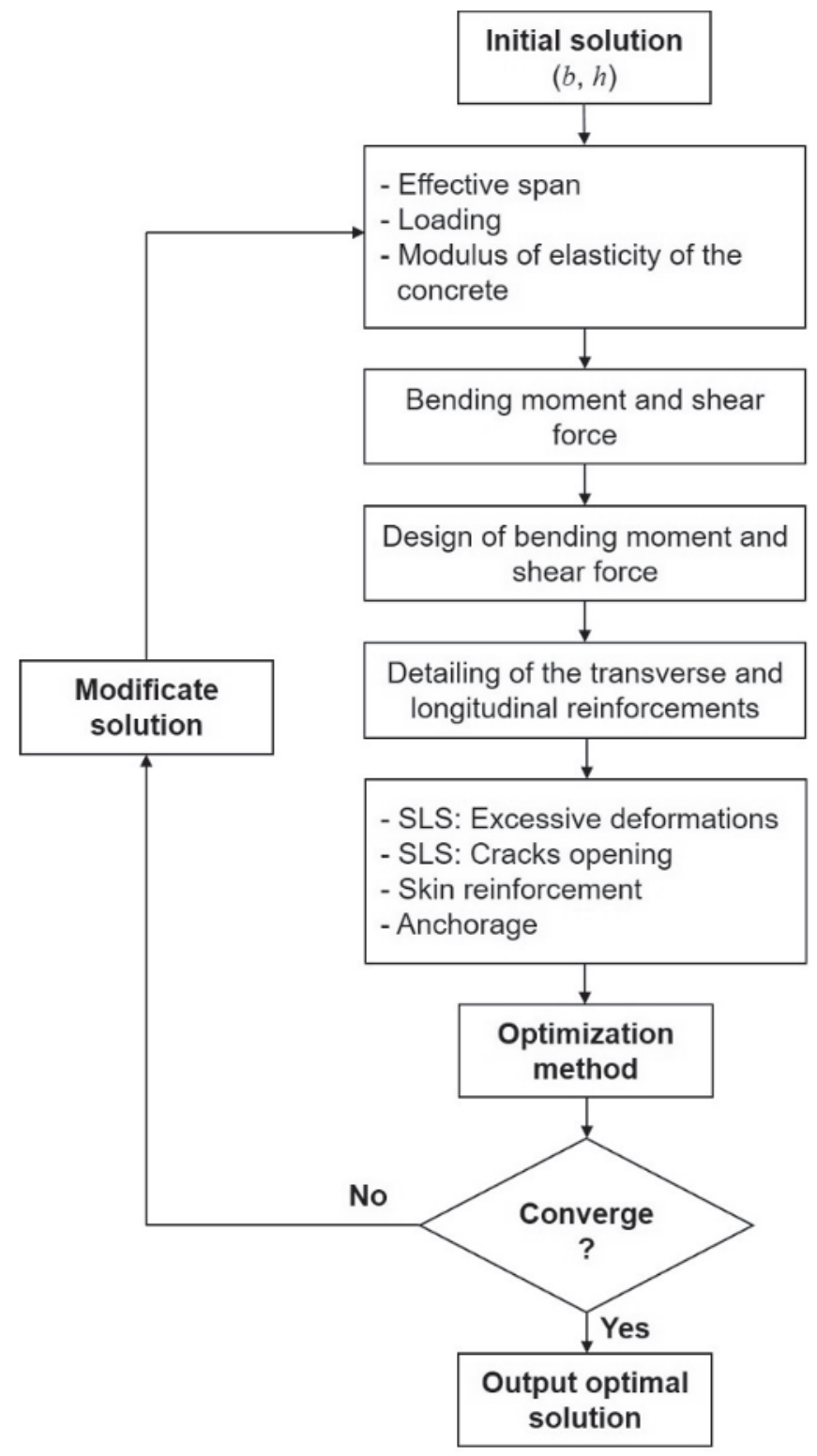

Figure 1

Flowchart of optimized dimensioning of the beam 


\begin{tabular}{|c|c|c|}
\hline \multicolumn{3}{|c|}{ Q } \\
\hline \multicolumn{2}{|l|}{ Standard Evolutionary Engine } & $\checkmark$ \\
\hline \multicolumn{3}{|c|}{$\therefore$ z $\downarrow$ ¿ $\square$ Automatically Select Engine } \\
\hline \multicolumn{2}{|c|}{ General } & $:=\hat{L} \downarrow$ \\
\hline \multicolumn{3}{|l|}{$\begin{array}{l}\text { Max Time } \\
\text { Iterations }\end{array}$} \\
\hline \multicolumn{3}{|l|}{ Iterations } \\
\hline Precision & $1 e-006$ & \\
\hline Convergence & 0,0001 & \\
\hline Population Size & 100 & \\
\hline Mutation Rate & 0,075 & \\
\hline \multicolumn{3}{|l|}{ Random Seed } \\
\hline Show Iterations & False & \\
\hline Use Automatic Scaling & True & \\
\hline Assume Non-Negative & False & \\
\hline Bypass Solver Reports & False & \\
\hline Require Bounds & True & \\
\hline Global Search & Genetic Algorithm & \\
\hline Local Search & Automatic Choice & \\
\hline Fix NonSmooth Variables & False & \\
\hline Model Based Search & None & \\
\hline Feasibility Pump & True & \\
\hline \multicolumn{3}{|l|}{ ⿴囗十 Limits } \\
\hline \multicolumn{3}{|l|}{ 田 Current Problem } \\
\hline \multicolumn{3}{|l|}{ 田 Engine Limits } \\
\hline
\end{tabular}

\section{Figure 2}

Solver dialogue box

optimization problem, seeking to use the most appropriate method [22]. Conducting this analysis in this study, it was found that this is a nonsmooth and nonconvex problem, and then the Evolutionary method is used.

In the Evolutionary settings, the values adopted for population size and mutation rate were 100 and 0.075 , respectively. Figure 2 show the Solver's "Engine" dialog box with the other parameters adopted.

\section{Analized structures}

The cross-sections of reinforced concrete beams were analyzed. The beams were considered to be supported on columns and sub- jected to a uniformly distributed loading. The cross-section is rectangular with width (b) and height (h), as shown in Figure 3. The columns have a square cross-section of $20 \mathrm{~cm}$. The steel used is class CA-50. The nominal cover is $30 \mathrm{~mm}$, being the Environmental Aggressiveness Class II. It is worth to highlight that this study did not considered the stiffness of the columns.

For the study of the beams cross-sections, the influence of the following parameters were analyzed: free span values, characteristic loading and class of characteristic compressive strength of the concrete. The free span values varied from $2 \mathrm{~m}$ to $7 \mathrm{~m}$ in increments of $0.50 \mathrm{~m}$, the characteristic loading varies from $10 \mathrm{kN} / \mathrm{m}$ to $50 \mathrm{kN} / \mathrm{m}$ in increments of $5 \mathrm{kN} / \mathrm{m}$ and the class of characteristic compressive strength of the concrete varies between $20 \mathrm{MPa}$ and $40 \mathrm{MPa}$ in increments of $5 \mathrm{MPa}$.

\section{Results and discussions}

With the implementation of beam design and the formulation of the Excel spreadsheet optimization problem, several optimized crosssections have been obtained that minimize its cost of the beam. The project variables adopted were the height and width of the beam.

Analyzing the combinations of the different values of free span (11 cases), loading (9 cases) and characteristic compressive strength of the concrete ( 5 cases), 495 optimized cross-sections were obtained. In the next few items, the numerical results and the main conclusions are presented.

\subsection{Height and width of optimized sections}

Initially, the authors studied how the height/span length ratio in the optimized cross-sections varies depending on the loading, span length and characteristic compressive strength of the concrete $\left(f_{C K}\right)$. Subsequently, the same analysis was carried out for the beam width.

In the pre-dimensioning stage, a usual approach to determine the height of the cross-sections of the reinforced concrete beams is the adoption of a height/ span length ratio of $10 \%$.
Structural model

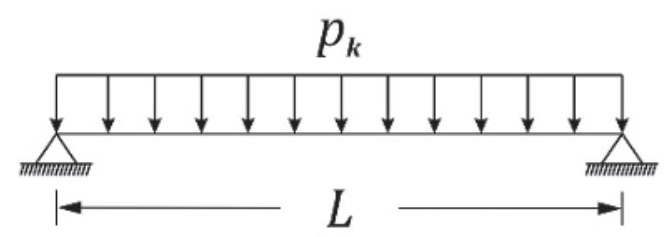

Longitudinal view

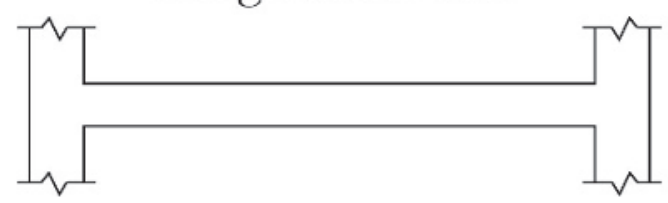

\section{Cross section}

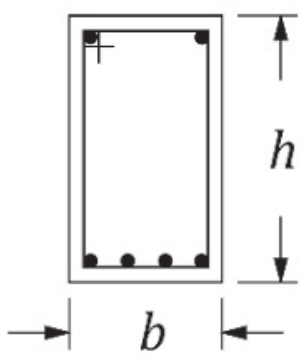

Columns $20 \times 20 \mathrm{~cm}$

Nominal cover $=30 \mathrm{~mm}$ Aggressiveness Class II

Figure 3

Studied beam model 

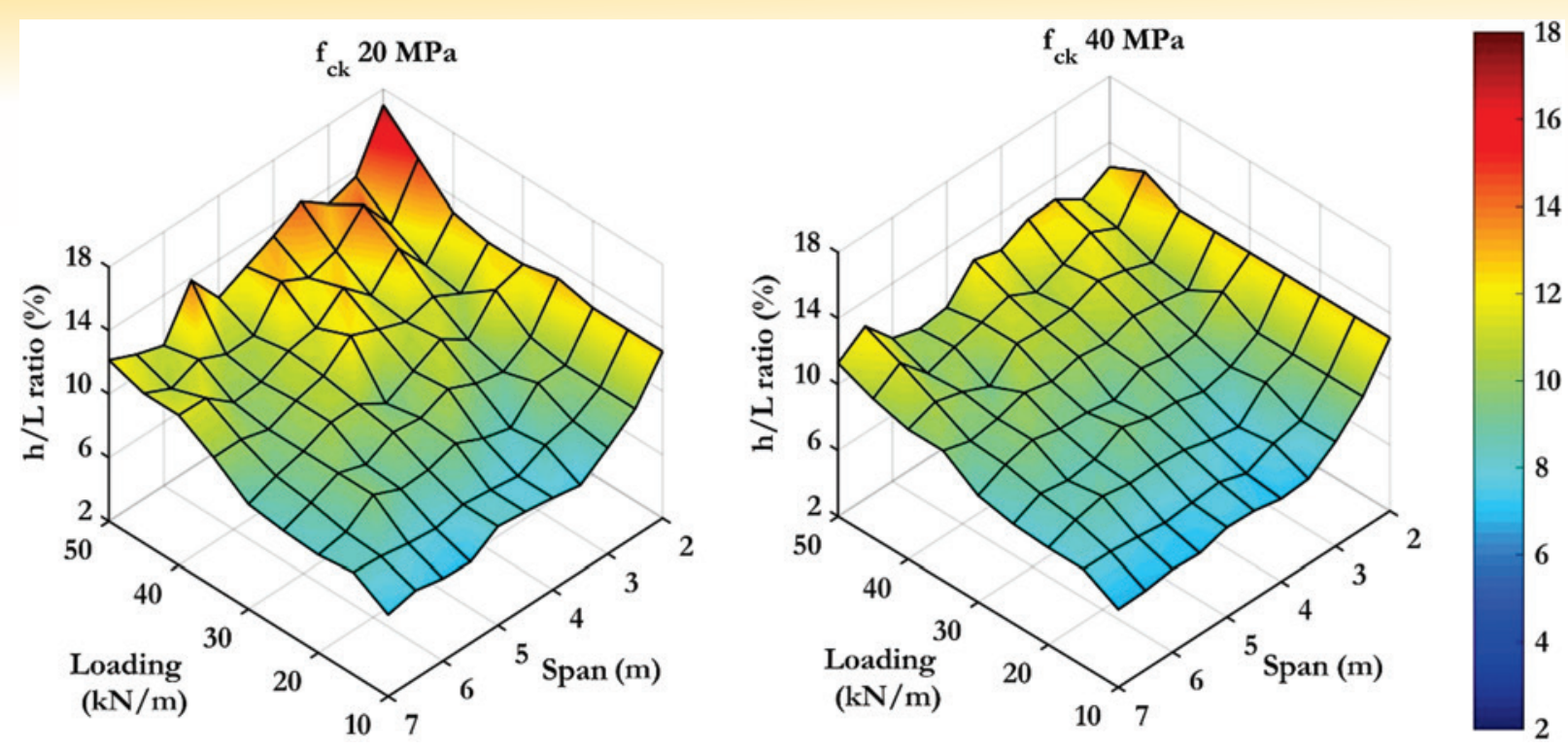

Figure 4

Optimum ratio (h/L) for span and loading, for concrete of $20 \mathrm{MPa}$ and $40 \mathrm{MPa}$

In the analyzed cases, it was observed that the values of $(\mathrm{h} / \mathrm{L})$ suffered small variations with the change of the $\mathrm{f}_{\mathrm{CK}}$. Figure 4 presents only the height/ span length $(\mathrm{h} / \mathrm{L})$ ratio for the $\mathrm{f}_{\mathrm{CK}}$ values of $20 \mathrm{MPa}$ and $40 \mathrm{MPa}$, depending on the free span and loading. It is observed that both surfaces present similar behavior, increasing the ratio $(\mathrm{h} / \mathrm{L})$, as the loading increases and span decreases. It must be highlighted that the ratio values $(\mathrm{h} / \mathrm{L})$ range from $7.10 \%$ to $17 \%$ in the case of $\mathrm{f}_{\mathrm{CK}}$ of $20 \mathrm{MPa}$, decreasing the maximum value to $13.50 \%$ in the case of $f_{C K}$ equal to $40 \mathrm{MPa}$. Considering small spans and high loading, the ratio becomes larger in the case of $f_{C K}$ equal to $20 \mathrm{MPa}$, due to the need for a greater height for this configuration.

In Figure 5 and Table 2, the arithmetic means of the $(\mathrm{h} / \mathrm{L})$ ratio is presented for each combinations of span length and loading, considering the 5 values of characteristic compressive strength of the concrete. It can be observed that the ratio $(\mathrm{h} / \mathrm{L})$ varies between $6.84 \%$ and $14.20 \%$ for the different configurations, and that from the 99 arithmetic mean calculated, a total of 40 varies between 9 and $11 \%$, i.e. these values are very close to the usual estimate of $10 \%$. There were 29 values $(\mathrm{h} / \mathrm{L})$ above $11 \%$, for these, the initial estimate adopted in the pre-dimensioning would employ values bellow the optimal values.

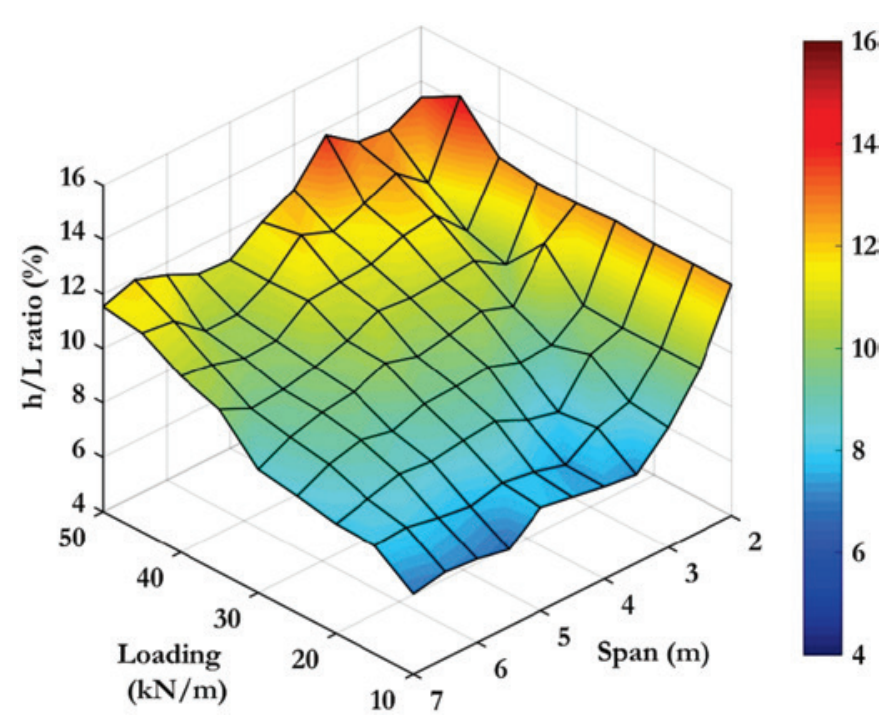

Figure 5

Average optimum ratio (h/L)

Table 2

(h/L) ratio for free span and loading (\%)

\begin{tabular}{ccccccccccc}
\hline \multirow{2}{*}{ Span $(\mathrm{m})$} & \multicolumn{10}{c}{ Loading $(\mathrm{kN} / \mathbf{m})$} \\
\cline { 2 - 9 } & $\mathbf{1 0}$ & $\mathbf{1 5}$ & $\mathbf{2 0}$ & $\mathbf{2 5}$ & $\mathbf{3 0}$ & $\mathbf{3 5}$ & $\mathbf{4 0}$ & $\mathbf{4 5}$ & $\mathbf{5 0}$ & $\begin{array}{c}\text { Average } \\
\text { ratio }(\%)\end{array}$ \\
\hline 2 & 12.50 & 12.50 & 12.50 & 12.60 & 12.50 & 12.50 & 12.70 & 14.20 & 13.40 & 12.82 \\
2.5 & $\mathbf{1 0 . 0 0}$ & $\mathbf{1 0 . 0 0}$ & $\mathbf{1 0 . 0 0}$ & $\mathbf{1 0 . 0 8}$ & 11.60 & $\mathbf{1 0 . 0 8}$ & $\mathbf{1 0 . 5 6}$ & 11.60 & 12.80 & $\mathbf{1 0 . 7 5}$ \\
3 & 8.40 & 8.60 & $\mathbf{9 . 6 0}$ & $\mathbf{9 . 2 0}$ & $\mathbf{9 . 8 7}$ & $\mathbf{1 0 . 8 0}$ & 11.73 & 12.53 & 12.93 & $\mathbf{1 0 . 4 1}$ \\
3.5 & 7.26 & 8.23 & 8.06 & $\mathbf{9 . 1 4}$ & $\mathbf{1 0 . 2 9}$ & $\mathbf{1 0 . 6 9}$ & 11.54 & 12.00 & 13.77 & $\mathbf{1 0 . 1 1}$ \\
4 & 7.40 & 7.45 & 8.35 & $\mathbf{9 . 5 5}$ & $\mathbf{1 0 . 0 0}$ & $\mathbf{1 0 . 6 0}$ & 11.10 & 11.55 & 12.35 & $\mathbf{9 . 8 2}$ \\
4.5 & 7.60 & 7.78 & 8.89 & $\mathbf{9 . 4 2}$ & $\mathbf{9 . 7 8}$ & $\mathbf{1 0 . 7 1}$ & 11.02 & 12.00 & 11.73 & $\mathbf{9 . 8 8}$ \\
5 & 7.80 & 7.96 & 8.76 & $\mathbf{9 . 3 6}$ & $\mathbf{1 0 . 1 2}$ & $\mathbf{1 0 . 2 0}$ & $\mathbf{1 0 . 9 2}$ & $\mathbf{1 0 . 8 8}$ & $\mathbf{1 0 . 9 2}$ & $\mathbf{9 . 6 6}$ \\
5.5 & 6.84 & 7.67 & 8.58 & 8.95 & $\mathbf{9 . 6 4}$ & $\mathbf{9 . 8 2}$ & $\mathbf{1 0 . 0 4}$ & $\mathbf{1 0 . 2 5}$ & $\mathbf{1 0 . 9 8}$ & $\mathbf{9 . 2 0}$ \\
6 & 7.07 & 7.83 & 8.70 & $\mathbf{9 . 2 0}$ & $\mathbf{9 . 4 7}$ & $\mathbf{9 . 5 7}$ & $\mathbf{9 . 9 7}$ & $\mathbf{1 0 . 2 3}$ & 11.53 & $\mathbf{9 . 2 9}$ \\
6.5 & 7.17 & 8.06 & 8.37 & 8.89 & $\mathbf{9 . 1 4}$ & $\mathbf{9 . 4 5}$ & $\mathbf{1 0 . 3 1}$ & 11.17 & 11.94 & $\mathbf{9 . 3 9}$ \\
7 & 6.94 & 7.97 & 8.03 & 8.31 & 8.54 & $\mathbf{1 0 . 0 0}$ & $\mathbf{1 0 . 4 9}$ & 11.31 & 11.54 & $\mathbf{9 . 2 4}$ \\
\hline
\end{tabular}



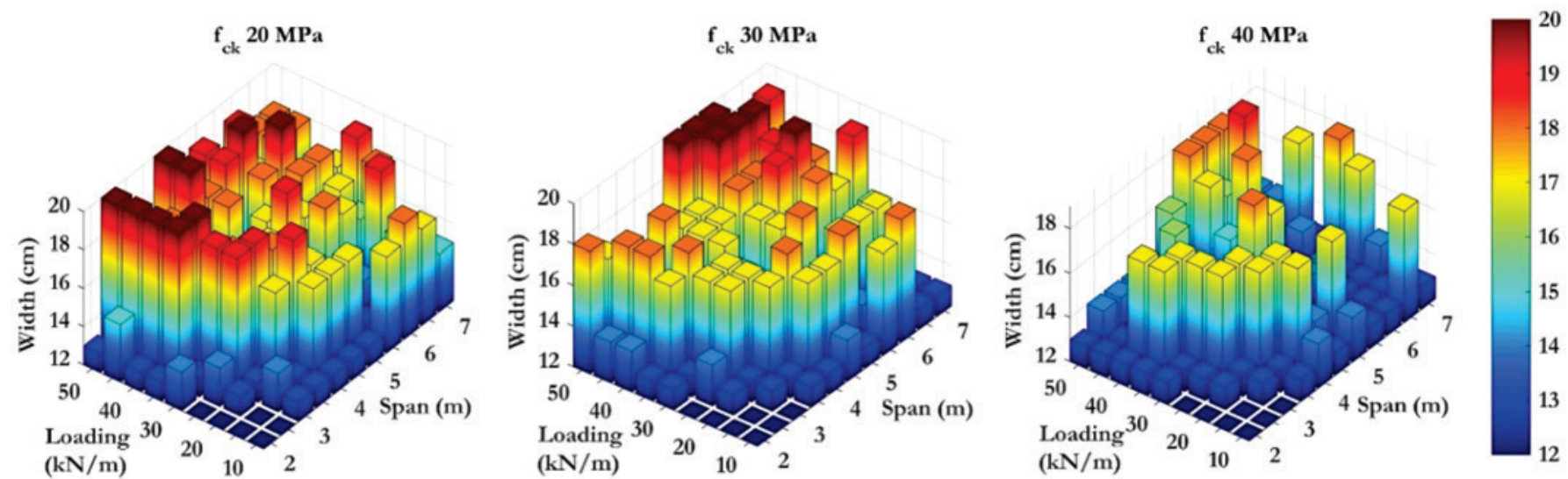

Figure 6

Optimum width values, considering concrete with $\mathrm{f}_{\mathrm{ck}} 20 \mathrm{MPa}, 30 \mathrm{MPa}$ and $40 \mathrm{MPa}$

In the last column of Table 2, the average ratio of $(\mathrm{h} / \mathrm{L})$ was calculated according to the span length, observing that among the 11 spans, 10 varies from 9.20 to $10.75 \%$. Therefore, the relationship adopted in the conventional pre-dimensioning can be considered acceptable since it was close to the optimal relationship.

Figure 6 presents the dimensions of the beam width optimized for three characteristic compressive strength of the concrete (20 MPa, $30 \mathrm{MPa}$ and $40 \mathrm{MPa}$ ) are shown as a function of the applied loading and the span length. It was observed that the width assumes different values in the various situations of span and loading, in order to meet the constraints and criteria of design and detailing considered previously. It can be noticed that most widths reduce their size, as the characteristic compressive strength of the concrete increases, since the increase of the resistance allows a decrease in the dimensions of the crosssections, without compromising the safety requirements. Moreover, this decrease in the cross-section dimensions due to the increase of the characteristic compressive strength of the concrete, is more evident in the width because of a height decrease could lead to the non-compliance of the Limit State of Excessive Deformation (restriction of eq. (8)).

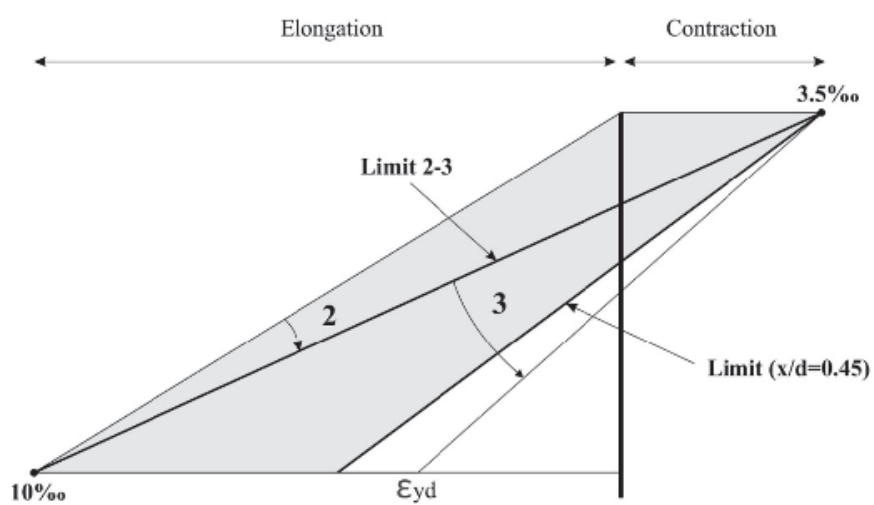

Figure 7

Strain domains of possible simple bending, for $\mathrm{f}_{\mathrm{ck}}$ less or equal to $50 \mathrm{MPa}$

\subsection{Full use of the materials in the optimized cross-sections}

It is expected that in the optimized cross-sections there is a great exploitation of the materials (concrete and steel), since the goal of optimization is to minimize the financial costs. In order to assess this use, it is necessary to analyze the strain of concrete and steel, as well as the strain domains.

The strain domains represents the various possibilities of collapse the section, characterized by the designed specific strain of concrete and steel, varying between domains 1 to 5 . The simple bending, is included within the domains 2,3 or 4 . In the domain 2, the concrete does not reach the rupture and the elongation of the tensile steel is the ultimate permitted $(10 \%)$, the rupture occurred due to the excessive plastic strain of the steel. In the domain 3, the compressed concrete reaches the ultimate strain of $3.5 \%$ and the tensile steel yield, the concrete ruptured by crushing. In the domain 4 , the concrete reaches the rupture, but the steel does not yield, and it is also characterized as a conventional rupture by crushing the concrete. Domain 3 represents an ideal situation, since both the crushing of the concrete and the yield of the steel occurs, being the materials (concrete and steel) used entirely and the collapse occurs with prior warnings (due to the large strains). In contrast, domain 4 represents an uneconomical situation since the steel is not used with its entire sturdy capacity and the rupture is fragile. Therefore, the cross-section of reinforced concrete must be dimensioned in the domain 3 because it is an economic situation. The domain 2 is acceptable and domain 4 must be avoided.

It was noticed that due to the limitations imposed to the position of the neutral line, 17.2.3 item of ABNT NBR 6118:2014 standard [13], part of domain 3 and domain 4 were not reached [23], as shown in Figure 7.

For the optimized cross-sections, the strain domains (domain 2 or 3 ) and the strains of the materials (steel and concrete) were obtained. This information is shown in Figure 8 and Table 3.

As shown in Figure 8, most of the cases analyzed are in domain 3 (approximately, $89 \%$ of the cases), while $11 \%$ are in domain 2. 
Table 3

Concrete and steel strains in optimum cross-sections

\begin{tabular}{cccc}
\hline \multicolumn{2}{c}{ Domain 2 } & \multicolumn{2}{c}{ Domain 3 } \\
\hline Concrete strains (\%०) & \% of optimum cross-sections & Steel strains (\%o) & \% of optimum cross-sections \\
\hline$\leq 1$ & 3.64 & $\leq 2.5$ & 0.00 \\
$1-2$ & 18.18 & $2.5-5$ & 52.27 \\
$2-3$ & 38.18 & $5-7.5$ & 33.86 \\
$3-3.5$ & 40.00 & $7.5-10$ & 13.87 \\
\hline
\end{tabular}

It is observed, in Table 3, in domain 3, that $52.27 \%$ of the sections have a steel strain between $2.5 \%$ and $5 \%$, while $33.86 \%$ had it between $5 \%$ and $7.5 \%$, and $13.87 \%$ presented values between $7.5 \%$ and $10 \%$.

In domain 2, according to Table $3,21.82 \%$ of the sections have the concrete strains up to $2 \%$, while $38.18 \%$ of the sections had it between $2 \%$ and $3 \%$, and $40 \%$ between $3 \%$ and $3.5 \%$. Therefore, most of the sections that are in domain 2 present strains in the concrete close to the ultimate strains of $3.5 \%$. Even if it is not in domain 3 , these sections also present a great use of the materials due to the large strains of the concrete.

\subsection{Optimized cross-sections costs}

In order to evaluate the economic advantages of the optimized crosssections, the costs were determined considering the height and width dimensions obtained in the implemented program (optimal solution), using an estimated height of $10 \%$ of the span and width equal to 20 $\mathrm{cm}$ (conventional solution). Based on these costs, the material saving of the optimized cross-sections was determined in relation to the pre-dimensioned sections, according to the conventional procedure. Table 4 presents the percentages of material saving for the sections, comparing to the solution optimized with the conventional solution. It was observed that more than $55 \%$ of the optimized sections present an material saving between $10 \%$ to $40 \%$. Approximately, $15 \%$ of the sections present a material saving below $5 \%$, since the estimated height is close to the optimal height. Among

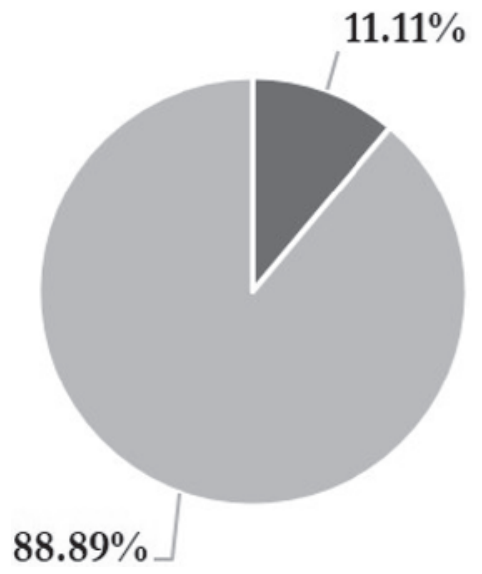

\section{- Optimized cross-sections of domain 2}

- Optimized cross-sections of domain 3

\section{Figure 8}

Optimized cross-sections from domains 2 and 3 in percentage the analyzed cases, the largest material saving obtained for an optimized cross-sections was $39 \%$.

Figures 9 and 10 present the material costs (concrete, steel and formwork) and the total cost of the optimized beams, for the characteristic compressive strength of the concrete of $20 \mathrm{MPa}$ and $40 \mathrm{MPa}$, depending on the loading applied and the length of the span. It was observed that the maximum costs were obtained in the case of $f_{C K}$ equal to $20 \mathrm{MPa}$, since due to a smaller resistance it is necessary sections with larger dimensions to provide adequate stiffness. It also turns out that the costs are higher in the situations with high span and loading, because, in these situations, more cross-section dimensions and steel areas are needed to support the requesting forces.

To analyze the influence of the cost parcels related to concrete, steel and formwork in the total cost of the beam, the average costs of these materials were obtained for all the analyzed cases.

Figure 11 presents the percentages of the materials costs in the total cost of the optimized cross-sections. It was observed that the cost of the formworks represents $66 \%$ in total cost, while the steel and concrete represents $25 \%$ and $9 \%$, respectively. It should be noticed that the percentage variation interval in relation to the total cost of formworks is approximately $50 \%$ to $79 \%$, for steel was from $12 \%$ to $41 \%$, and for concrete was from $7 \%$ to $13 \%$.

It is important to highlighted that the cost percentages presented previously are related to the optimization problem formulated with the unitary costs from Table 1. Also, it is worth pointing out that different unitary cost values will produce other optimal results, respecting the constraints imposed on the problem.

\section{Conclusions}

The reinforced concrete beams are structural elements that are

\section{Table 4}

Optimized sections savings, when compared with the pre-dimensioned sections used in the conventional procedure

\begin{tabular}{cc}
\hline Savings (\%) & \% of optimized cross-sections \\
\hline$\leq 5$ & 14.96 \\
$5-10$ & 27.57 \\
$10-15$ & 17.60 \\
$15-20$ & 15.54 \\
$20-25$ & 10.26 \\
$25-30$ & 9.09 \\
$30-35$ & 3.81 \\
$35-40$ & 1.17 \\
\hline
\end{tabular}



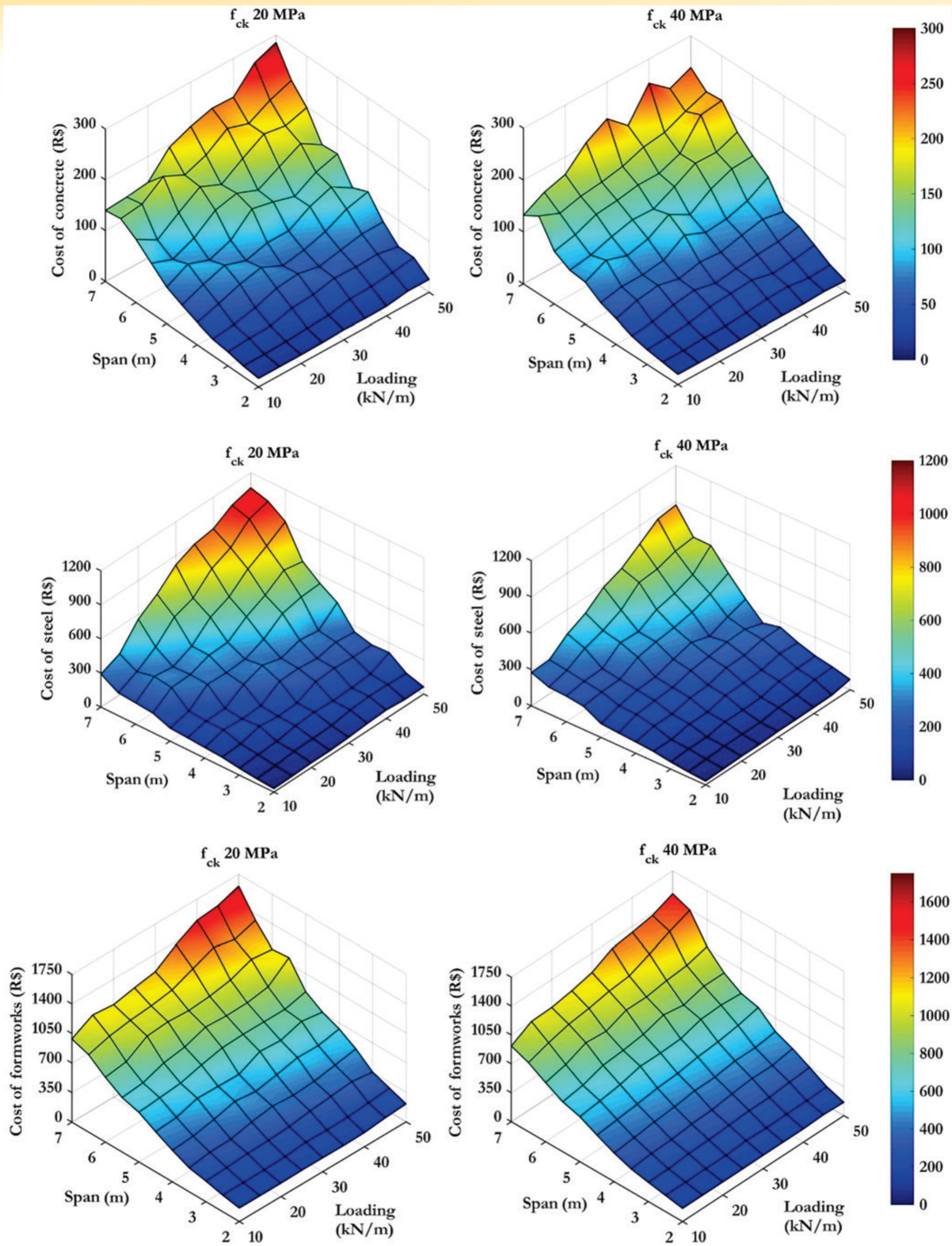

\section{Figure 9}

Costs (R\$) of materials (concrete, steel and formworks) in the optimized cross-sections, for concrete of $20 \mathrm{MPa}$ and $40 \mathrm{MPa}$ 

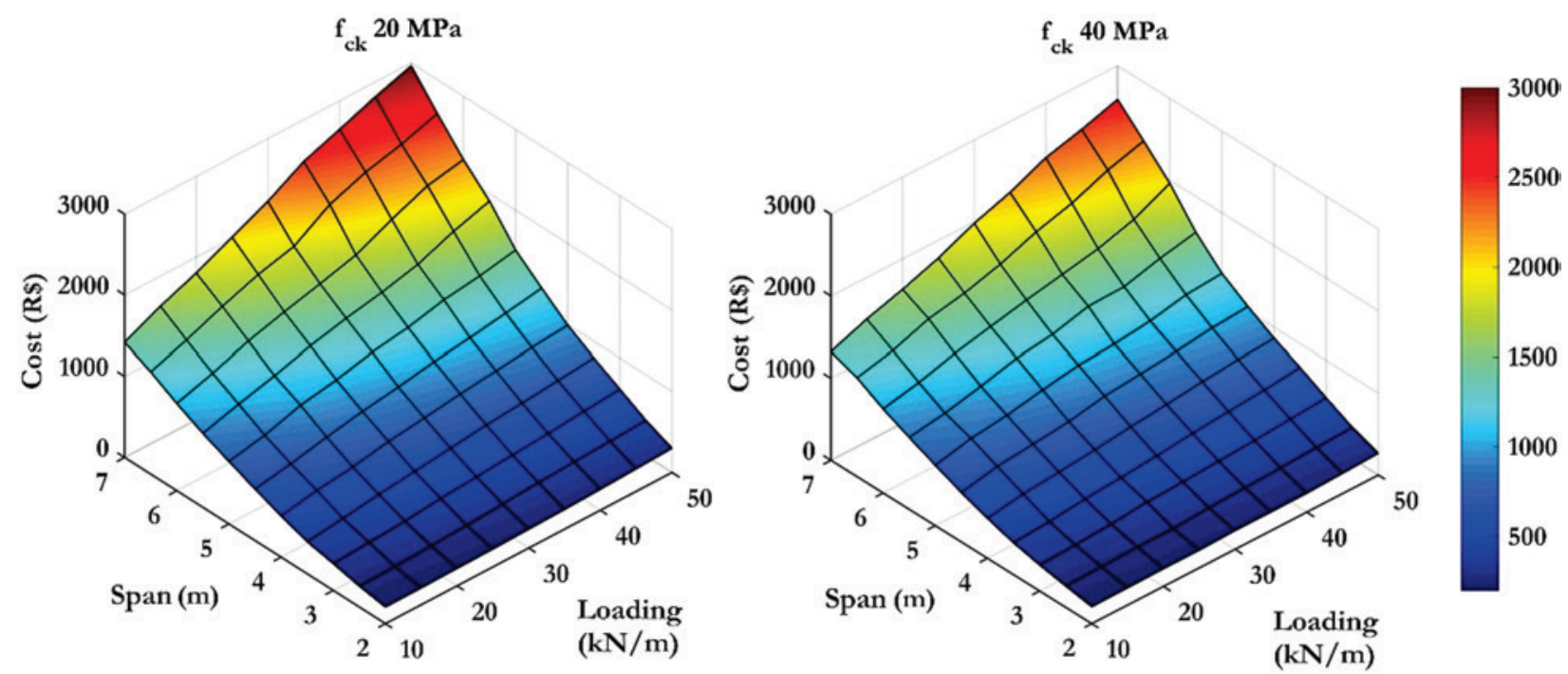

Figure 10

Total costs (R\$) in optimized cross-sections, for concrete of $20 \mathrm{MPa}$ and $40 \mathrm{MPa}$

quite common in civil construction. Thus, a reduction in their costs can bring significant material saving to this sector.

In this work, optimization techniques were implemented, using the Solver tool, to the procedure of design of reinforced concrete beams, following the precepts of the Brazilian Standard ABNT NBR 6118:2014. The total cost (concrete, steel and formworks) of reinforced concrete beams was minimized, considering as design variables the height and width of the beam cross-sections.

The conclusions related to the optimization study of reinforced concrete beams are presented below, considering 11 span lengths, 9 loadings and 5 characteristic compressive strength of the concrete:

- The estimate of the beam height, $10 \%$ of the free span, can be considered generally a good estimative, since it approaches the ratio of optimal height per span;

- Because they bring a very significant cost economy, the optimized cross-sections are advantageous in relation to the predimensioned cross-sections, according to the conventional

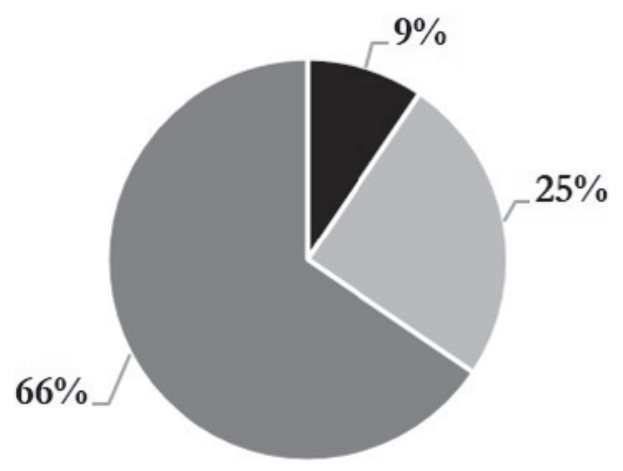

\section{- Concrete \\ Steel}

- Formworks

\section{Figure 11}

Costs percentage of materials in the total cost of the optimized cross-sections procedure, using an estimated height of $10 \%$ of the span and width equal to $20 \mathrm{~cm}$. As seen in the Section 5 Results and discussions, this approach may lead to a material saving of $35 \%$;

- In fact, the optimized cross-sections present a great use of the materials (concrete and steel), once that most of them are in the domain 3, and even those in the domain 2 have large strains (close to the ultimate strains);

- In the construction of the financial costs, it was observed that the formworks cost represented the highest percentage in the total cost of the optimized cross-sections, followed by steel and concrete, respectively. This result is related to the optimization problem formulated for reinforced concrete beam, with the unitary costs of Table 1, and it may vary for other costs and different structural elements.

\section{Aknowledgements}

The authors would like to thank Frontline Systems for providing an educational version of the Analytic Solver Platform for the performance of this study.

And to CAPES for the financial support to the research project.

\section{References}

[1] LOPES, A.F.O., BONO, G.F.F., BONO, G. Análise Numérica Comparativa entre Lajes Maciças e Nervuradas com diferentes tipos de Materiais de Enchimento. Mecánica Computacional, v.XXXII, 2013; p.3483-3495.

[2] LOPES, A.F.O., BONO, G.F.F., BONO, G. Análise entre Lajes Nervuradas Moldadas no local e Lajes Pré-fabricadas Treliçadas. In: Congresso Brasileiro do Concreto, $57^{\circ}$, Bonito, 2015, Anais.

[3] GALEB, A. C. Optimum design of reinforced concrete rectangular beams using simulated annealing. The Iraqi Journal For Mechanical And Material Engineering, Edição especial, 2009. 
[4] GUERRA, A., KIOUSIS, P.D. Design optimization of reinforced concrete structures. Computers and Concrete, v.3, n.5, 2006; p.313-334.

[5] ALGEDRA, M., ARAFA, M., ISMAIL M. Optimum Cost of Prestressed and Reinforced Concrete Beams using Genetic Algorithms. Journal of Artificial Intelligence, v.4, n.1, 2011; p.76-88.

[6] SINGH, B., RAI, H.S. Optimisation of RCC Beam. International Journal of Engineering, Business and Enterprise Applications, ed.9, v.1, 2014; p.21-34.

[7] MAIA, J.P.R. Otimização estrutural: estudo e aplicações em problemas clássicos de vigas utilizando a ferramenta Solver, São Carlos, 2009, Dissertação (Mestrado) - Universidade de São Paulo, 83 p.

[8] KRIPKA, M., PAGNUSSAT, R. Parâmetros para o dimensionamento otimizado de vigas de concreto armado. Revista Téchne, ed.160, julho/2010.

[9] BHALCHANDRA, S.A., ADSUL, P.K. Cost Optimization Of Doubly Reinforced Rectangular Beam Section. International Journal of Modern Engineering Research, ed.5, v.2, 2012; p.3939-3942.

[10] RAHMANIAN, I., LUCET Y., TESFAMARIAM S. Optimal design of reinforced concrete beams: A review. Computers and Concrete, v.13, n.4, 2014; p.457-482.

[11] JUNIOR, F.H.M.M., OLIVEIRA, D. M. Otimização de vigas de concreto armado com seção retangular submetidas à flexão normal simples. Construindo, Belo Horizonte, v.6, n.1, 2014; p.51-57.

[12] FRAGA, J.L.T., KRIKPA, M. Projeto Estrutural de Vigas de Concreto Armado visando a Minimização do Impacto Ambiental. Revista de Engenharia e Tecnologia, v.7, n.1, 2015; p.123-131.

[13] ASSOCIAÇÃO BRASILEIRA DE NORMAS TÉCNICAS NORMA BRASILEIRA. Projeto de estruturas de concreto Procedimento, NBR 6118. Rio de Janeiro: ABNT, 2014, 238 p.

[14] SINAPI - SISTEMA NACIONAL DE PESQUISA DE CUSTOS E ÍNDICES DA CONSTRUÇÃO CIVIL. Caixa Econômica Federal, Dezembro, 2016.

[15] <https://www.solver.com/analytic-solver\%C2\%AE-platform>.

[16] <https://www.solver.com/>.

[17] FRONTLINE SOLVERS. Excel Solver Help. Disponível em <http://www.solver.com/excel-solver-help>. Acesso em 17 de março. 2016.

[18] LUENBERGER, D.G., YE, Y. Linear and Nonlinear Programming. New York: Springer, 3ed, 2008.

[19] ARORA, J.S. Introduction to Optimum Design. Elsevier Academic Press, 3ed, 2012.

[20] HAUPT, R.L., HAUPT, S.E. Practical Genetic Algorithms. New Jersey: John Wiley \& Sons, 2ed, 2004.

[21] MELANIE, M. An Introduction to Genetic Algorithms. MIT Press, 1996.

[22] RAGSDALE, C. T. Modelagem de planilha e Análise de Decisão: uma introdução prática a business analytics. São Paulo: Cengage Learning, 2014.

[23] CARVALHO, R. C.; FILHO, J. R. de F. Cálculo e detalhamento de estruturas usuais de concreto armado: segundo a NBR 6118:2014. São Carlos: EdUFSCar, 2014. 